\title{
John Locke on Conversation with Friends and Strangers
}

\section{Richard Yeo}

John Locke did not write an 'essay' on the standard humanist topic of friendship; yet his letters, notebooks, and major works contain significant reflections on it, if not a systematic position. This article considers what Locke thought about the importance of conversation, often paired in humanist writings with the ideal of a perfect friendship between two equals. He entertained a version of this notion, asserting that best friends must be lovers of truth, but also valued informal exchanges with strangers as sources of new information and ideas. For Locke, conversation with both friends and strangers was a necessary instrument in the pursuit of truth.

In 1702, shortly before his death, the English philosopher and physician, John Locke (1632-1704), suffered severe loss of hearing. He told Edward Clarke that 'I have been little better than out of the world these last twelve months by a deafness that in great measure shut me out of conversation.' ${ }^{1}$ In a letter of 12 January 1705, Damaris Masham replied to Jean Le Clerc's request for her memories of 'our dead Friend', ${ }^{2}$ reporting that Locke had once said that he would prefer 'to be Blind than Deaf'. ${ }^{3}$ We can accept, then, that Locke

1 John Locke to Edward Clarke, 30 November 1702 (letter no. 3223) in The Correspondence of John Locke, ed. E. S. de Beer, 8 vols (Oxford: Clarendon Press, 1976-89). For other letters concerning Locke's deafness, see nos 3076, 3082, 3089, 3195. De Beer's edition is cited hereafter as Correspondence, and I give number only, omitting volume and page. In quotations from seventeenth-century texts, I preserve original spelling and punctuation but expand contractions.

2 Damaris Masham to Jean Le Clerc, 12 January 1705, in Jean Le Clerc, Epistolario, 4 vols, eds Maria Grazia and Mario Sina (Firenze: L. S Olschki, 1987-1994), II, p. 497. Masham's account was used in Jean Le Clerc, The Life and Character of Mr John Locke ... done into English by T. F. P. Gent (London: John Clark, 1706). This was originally published in the Bibliothèque Choisie, 6 (1705), 342-411. Locke died on 28 October 1704.

3 This remark from the final passage of Masham's letter to Le Clerc is illegible in the original manuscript held in the Universiteits-Bibliotheek, Amsterdam (MS R. K., J 57 a); Grazia and Sino do not print it. However, it occurs in this form in the English translation of Le Clerc's transcription (see Le Clerc, Life and Character, p. 30). Michel de Montaigne had already contemplated this: 'To my taste, the most fruitful and most natural exercise of our 
truly feared that deafness would exclude him from conversation, which he believed to be one of the great channels and benefits of friendship. In this essay I add a complication by stressing that Locke viewed conversation not only as the principal medium of friendship, but as a vital instrument in the pursuit of truth; it therefore figured in his life-long concern about the proper grounds of assent and belief. ${ }^{4}$ One implication was that conversation need not always be coupled with friendship; talk with strangers might be just as important if it assisted the search for knowledge and truth.

It is important to note that the word 'conversation' was used in two main senses in the early modern period. In its wider, and older, sense it meant the act of living with and sharing the company of others. An English translation of Don Quixote in 1620 has it that 'You may know the man, by the conversation he keepes', referring to the company in which that person lived. ${ }^{5}$ In this sense, one did not have 'conversation' with strangers. The second, more specific, meaning is the one now familiar to us: namely, the act of speaking and discussing with others. By the end of the seventeenth century this was becoming the dominant sense, and it is evident in Masham's letter to Le Clerc. Even so, we can hear the wider referents: for example, in her remark that Locke 'convers'd with books', and in her need to specify his 'personal Conversation' and 'ordinarie Conversation'. We can also appreciate how friendship was regarded as a special case of the wider sense of sharing company - in this case, with an equal rather than with kinsfolk, who were also seen as 'friends'. Thus Masham reported that among the 'contentments' Locke enjoyed in London after his return from Holland in 1689 was 'that

minds is conversation ... if I were now obliged to make the choice, I think I would rather lose my sight than my powers of speech or hearing' (Michel de Montaigne, 'On the Art of Conversation', in The Complete Essays, trans. M. A. Screech (London: Penguin Books, 1991), Book III, no. 8, pp. 1044-69 (p. 1045)).

4 On the first page of Draft B (1671) of his Essay Concerning Human Understanding (1690), hereafter cited as Essay, Locke announced his aim of inquiring into 'the grounds \& degrees of Opinion Belief Perswasion or Assent which I thinke take in all those things which are the objects of our thoughts \& all the ways wherein our Understandings can be imploid about them' (Drafts for the Essay Concerning Human Understanding and Other Philosophical Writings, eds Peter H. Nidditch and G. A. J. Rogers, 3 vols (Oxford: Clarendon Press, 1990-), I, pp. 101-02).

5 Miguel de Cervantes, The Second Part of the History of ... Don Quixote of the Mancha, trans. Thomas Shelton (London: E. Blount, 1620), p. 458. This is cited in the Oxford English Dictionary as an illustration of the older meaning.

Parergon 26.2 (2009) 
of spending one day every week with my lord Pembroke in a Conversation undisturb'd by such as could not beare a part in the best entertainment of Rational Minds, Free Discourse concerning usefull Truths'. ${ }^{6}$ As we shall see, Locke had high expectations about this kind of friendship, but he also believed that truths about useful matters could be obtained through conversation with strangers. ${ }^{7}$

The Stoic revival in sixteenth- and seventeenth-century Europe provided an influential framework that linked conversation with a special kind of friendship. Justus Lipsius' Constantia (1584), written as a dialogue with his friend (Langius), gave new life to Lucius Annaeus Seneca's avowal of close friendship as a safe haven from the chaos of politics. Lipsius advocated patience, self-control, and strength of mind against the backdrop of the wars of religion in France and the civil wars in the Netherlands. In Book Two, the two friends meet in a garden to 'refresh ... [their] wearied and wandering minds', and they celebrate the quiet space in which philosophers have meditated and discussed 'constancy, life, and death' ${ }^{8}$ Neo-Stoicism was consolidated by new editions and translations of Seneca's De Beneficiis, his Epistulae Morale, and his Works (1606), edited by Lipsius, and Marcus Tullius Cicero's De Amicitia and De Officiis. The influence of these authors is apparent in contemporary works such as Stefano Guazzo's De civile conversatione (1574) and Michel de Montaigne's Essais (1580-88). ${ }^{9}$

Locke encountered these works of Seneca and Cicero at Westminster school in London. From 1658, while at Christ Church, Oxford he made entries and

6 Masham to Jean Le Clerc, Epistolario, II, pp. 492, 502, 508. This was Thomas Herbert, Eighth Earl of Pembroke, to whom Locke dedicated the Essay.

7 For the nuances of friendship and conversation in early modern contexts, see Keith Thomas, The Ends of Life: Roads to Fulfilment in Early Modern England (Oxford: Oxford University Press, 2009), pp. 187-225; for the shifting relation between public and private, see Conal Condren, 'Public, Private and the Idea of the "Public Sphere" in Early-Modern England', Intellectual History Review, 19 (2008), 15-28.

8 Justus Lipsius, On Constancy, trans. Sir John Stradling (1595), ed. John Sellars (Exeter: Bristol Phoenix Press, 2008), p. 80. More generally, see Peter Burke, 'Humanism and Friendship in Sixteenth-Century Europe', in Friendship in Medieval Europe, ed. Julian Haseldine (Stroud: Sutton, 1999), pp. 262-74.

9 For Locke's copies of Cicero, Seneca, Lipsius, Guazzo, and Montaigne, see John Harrison and Peter Laslett, The Library of John Locke, 2nd edn (Oxford: Clarendon Press, 1971), nos. 721, 1351, 1763, 2029, 2612-16. 
extracts in his notebooks. ${ }^{10}$ In letters to the people he counted as friends, Locke showed awareness of these Stoic values (especially as transmitted via Cicero): he assured the Remonstrant theologian, Philip van Limborch (they met in 1684 during Locke's exile in Holland), that 'no one anywhere exists who is readier to fulfil all the duties of friendship (omnia amicitiae officitia)'. He told Benjamin Furly, an English Quaker and bibliophile living in Holland, 'I am truly your friend, and love you'. ${ }^{11}$ John Dunn has suggested that, for Locke, 'Friendship is the only psychically worthwhile form of terrestrial riches because it is the only relationship between human beings in which moral solidarity may be depended upon'. ${ }^{12}$ Indeed in his earliest work, the Essays on the Law of Nature, written in Latin in 1663-64, Locke stated that trust is the bond of society (societatis vinculum fides); and this trust was not solely based on utility or expediency - otherwise 'all justice, friendship, and generosity are taken away from life'. ${ }^{13}$ In 1671, in the first draft of the Essay Concerning Human Understanding (1690), he categorized the idea of friendship as a relational one, saying that it was easier to conceive 'what a freind is then [sic] what god'. ${ }^{14}$ For Locke, this

10 For entries in his notebooks, see John Marshall, John Locke: Resistance, Religion and Responsibility (Cambridge: Cambridge University Press, 1994), p. 164, n. 10; and Victor Nuovo, 'Aspects of Stoicism in Locke's Philosophy', in Studies on Locke: Sources, Contemporaries, and Legacy, eds Sarah Hutton and Paul Schuurman (Dordrecht: Springer, 2008), pp. 1-25 (p. 3, ns 3 and 8).

11 Locke to Limborch, 12 April 1689, Correspondence, no. 1127; Locke to Furly, 28 April 1691, Correspondence, no. 1386; see William I. Hull, Benjamin Furly and Quakerism in Rotterdam (Swarthmore, Pa.: Swarthmore College, 1941), pp. 82-100. For Limborch, see Maurice Cranston, John Locke: A Biography (London: Macmillan, 1957), pp. 233-38. Marshall observes that 'friendship was central to Locke's ethics, to his personal intellectual life of discussion of ideas, and to his description of the centre of the desirable intellectual and moral life of other men' (John Locke, p. 78).

12 'From Applied Theology to Social Analysis', in Wealth and Virtue, eds Istvan Hont and Michael Ignatieff (Cambridge: Cambridge University Press, 1983), pp. 119-36 (p. 127). Philip Abrams suggests that Locke sought refuge from the political disorder of the Interregnum in personal relationships, but he notes that these were governed by 'elaborate formal civility'. See John Locke, Two Tracts on Government, ed. Philip Abrams (Cambridge: Cambridge University Press, 1967), pp. 52-53.

13 Essays on the Law of Nature, ed. W. von Leyden (Oxford: Oxford University Press, 1954), pp. 212-13. See also pp. 108-11 for his acknowledgment of the conception of natural law in the 'the Stoics'.

14 Draft A, Drafts for the Essay, eds Nidditch and Rogers, I, p. 34.

Parergon 26.2 (2009) 
relationship involved beneficence, gratitude, and mutual obligation - close to the formulation of Lipsius.

There remains, however, a significant challenge in discussing Locke's ideas about friendship. The undoubted significance of actual friendships in his life is not matched by any sustained treatment of this idea, despite his awareness of its importance for Aristotle and the Stoics. ${ }^{15}$ Unlike Montaigne and Francis Bacon, Locke did not compose 'essays' on this topic, a standard one in Renaissance humanism. Certainly, there is nothing resembling Montaigne's account of the 'true and perfect friendship' between himself and Etienne de La Boëtie. ${ }^{16}$ In what might be Locke's only allusion to this Aristotelian notion of the perfect friendship between equal minds, he suggested that men 'often love their friends with whose good offices or conversation they are delighted'. ${ }^{17}$ He thereby implied that utility and pleasure (the hallmarks of Aristotle's two lesser forms of friendship) continued to operate even in the best of friendships. ${ }^{18}$ Aristotle did not deny this, but he defined the highest form of friendship as one principally devoted to the recognition and promotion of the goodness of the person. In contrast, Locke continued that what 'we call love of their friends is not truly love of their persons but a care to preserve with their persons and friendship those good things which they do love

15 A full comparative study of Locke's relationships with Edward Clarke, Damaris Masham, Benjamin Furly, Philip van Limborch, John Maplecroft, Nicolas Toinard, and James Tyrrell might tell us more. See Mark Goldie, 'Introduction', in John Locke: Selected Correspondence, ed. Mark Goldie (Oxford: Oxford University Press, 2002), pp. xi-xxvii. Locke's friendship with Masham is of great interest; see Jacqueline Broad, 'A Woman's Influence? John Locke and Damaris Masham on Moral Accountablity', Journal of the History of Ideas, 67 (2006), 489-510.

16 Michel de Montaigne, 'On Affectionate Relationships' (usually called 'On Friendship'), in his Complete Essays, Book I, no. 28, pp. 205-19 (p. 208).

17 John Locke, Journal, 16 July 1676, MS Locke f. 1, pp. 326-28 (p. 327). This entry was written in shorthand under the marginal heading 'Love'. A transcription from the shorthand is printed in Locke, Essays on the Law of Nature, ed. von Leyden, p. 266. Unless otherwise noted, references to Locke manuscripts are to those in the Lovelace Collection, Bodleian Library, Oxford.

18 Aristotle, The Nichomachean Ethics, trans. J. A. K. Thomson, intro. Jonathan Barnes (London: Penguin, 2004), books VIII and IX. See also Lorraine S. Pangle, Aristotle and the Philosophy of Friendship (Cambridge: Cambridge University Press, 2003). For similarities between Aristotle and the Stoics on friendship, see Margaret R. Graver, Stoicism and Emotion (Chicago: Chicago University Press, 2007), p. 250, n. 3. 
and which they cannot have without them'. ${ }^{19}$ One of these 'good things', I propose, was conversation, both as an enjoyable activity and as a crucial aid in the pursuit of truth. For Locke, the search for knowledge and truth was the prime moral duty of each individual in his life of probation on earth, our 'twilight State', as he called it. In the Essay, he delineated the limits of our rational faculties, but never denigrated these divinely bestowed capacities which were 'bright enough for all our Purposes' and, if properly used, would discern both natural and moral knowledge. ${ }^{20}$

I suggest that, for Locke, important truths were most safely sought in partnership with close friends. This was especially the case in what he called 'matters of concernment' (such as moral and religious questions). Although the individual was ultimately responsible for such beliefs, Locke advised that it was wise to seek the help of friends possessing sound judgement. In the final section of this essay, I consider this point in the light of his relationship with William Molyneux, a friendship formed by correspondence rather than by conversation. However, Locke also held that friendship involved risks that were not entailed by conversation with strangers. There is strong testimony about his exchanges with a diverse range of people who were not friends. Masham noted this in her letter to Le Clerc, saying that his 'Company was exceedinly acceptable to all sorts of men, [yet] it was no less so to Ladys'. She added that this ease was not expected in 'the Character of a Scholar and Learned man'. ${ }^{21}$ Locke wanted to retain the advantages of close friendships among scholars; but as a member of the Royal Society of London, he also welcomed the more open civility that encouraged fruitful contacts with foreign correspondents and with learned gentlemen and skilled artisans encountered on travels. By recognizing this spectrum of conversations, often mirroring different degrees of friendship, we can gain some insight into the importance Locke placed on both critical dialogue with trusted friends and more transient exchanges with strangers. I draw from a selection of his published writings, letters, and private notes.

19 Journal, 16 July 1676, p. 328; also in Locke, Essays on the Law of Nature, p. 266.

20 John Locke, An Essay Concerning Human Understanding, ed. Peter H. Nidditch (Oxford: Clarendon Press, 1975), IV.xiv.2 and I.i.5. See also John Dunn, 'Bright Enough for all our Purposes: John Locke's Conception of a Civilized Society', Notes and Records of the Royal Society of London, 43 (1989), 133-53.

21 Masham to Le Clerc, Epistolario, II, p. 512.

Parergon 26.2 (2009) 


\section{Types of Conversation}

The preference for hearing over sight implied that reading of books, and even perhaps letters, was not a substitute for real conversation. Indeed, Montaigne contrasted conversation with bookishness: 'Studying books has a languid feeble motion, whereas conversation provides teaching and exercise all at once'. ${ }^{22}$ Locke took a similar view. He must have made this clear to his friends, for in seeking to portray Locke's character, his French translator, Pierre Coste, reported that:

Mr Locke also thought it necessary always to communicate one's thoughts to some friend ... He could hardly conceive how a being of so limited a capacity as man, and so subject to error, could have the confidence to neglect this precaution. ${ }^{23}$

Because he placed so much weight on this point, Locke was fastidious about the right kind of conversation. At its best, it made life worth living - a sentiment voiced by Damaris Masham and repeated by Locke: 'My Lady ... says that in this uncertain world she knows noe thing soe desirable as the conversation of friends'. ${ }^{24}$ However, Locke castigated the kind of talk that either posed as proper conversation or wasted the time in which it might occur. It is striking that this kind of worthless exchange featured in his operational definition of pain and pleasure: 'The pain of tender Eyes, and the pleasure of Musick; Pain from captious uninstructive wrangling, and the pleasure of rational conversation with a Friend, or of well directed study in the search and discovery of Truth'. The mention of wrangling signals his well-known contempt of university disputations with their prospect of 'bookish Men, devoted to some Sect, and accustomed to the Language of it; and [who] have learned to talk after others' (Essay, II.xx.18; II.xiii.27). ${ }^{25} \mathrm{He}$

22 Montaigne, 'On the Art of Conversation', p. 1045. A similar point is made in Henry Peacham, The Compleat Gentleman (London: Francis Constable, 1634), pp. 25-26.

23 Pierre Coste, 'The Character of Mr. Locke', in The Works of John Locke. A new edition, corrected, 10 vols (London: printed for Thomas Tegg and others, 1823), X, pp. 162-74 (p. 171). This first appeared in Nouvelles de la République des Lettres, February 1705; it was published in English in A Collection of Several Pieces of Mr. Locke, ed. Pierre Des Maizeaux (London: J. Bettenham for R. Francklin, 1720), pp. iv-xxiv.

24 Locke to Edward Clarke, 30 November 1702, Correspondence, no. 3223.

25 Masham to Le Clerc, Epistolario, II, p. 500 cites James Tyrrell's memory of Locke's aversion to university disputations. This stance was one element in his conception of how a philosopher should behave. See Richard Yeo, 'John Locke and Polite Philosophy', in 
also directed similar, albeit less ferocious, invective against the pedantry that relied on commonplace books filled with a 'stock of borrowed and collected arguments'. This kind of education produced the worst conversation partner, 'the topical man', constantly in danger of contradicting himself. ${ }^{26}$

Of somewhat less concern was the banter and repartee of aristocratic wit. Locke had little exposure to the inner court, but from 1667 he became a member of the household of Anthony Ashley Cooper (created First Earl of Shaftesbury in 1672). Locke was Shaftesbury's trusted advisor and tutor to both his son and grandson. In a letter of 8 February 1705 to Jean Le Clerc, the Third Earl of Shaftesbury (grandson of the first Earl), supplied this revealing anecdote. The scene is a private gathering of the Shaftesbury circle, including the Duke of Buckingham and Lord Halifax:

after a few Compliments the Cards were calld for, and the Court Fashion prevailing, they were engagd in Play before any Conversation was begun. Mr. Lock sate by, as a Spectator for some time; at last taking out his Table Book, he began to write something very buisily: till being observd by one of the Lords, and ask'd what he was meditating; My Lords (sayd he) I am improving my self the best I can in your Company; for, having impatiently wayted this Honour of being present at such a meeting of the wisest Men and greatest Witts of the Age, I thought I could not do better than to write your Conversation: and here I have it, in substance, all that has pass'd for this hour or two. There was no need of Mr. Lock's reciting much of the Dialogue. The great Men felt the ridicule, and took pleasure in improving it. They quitted their Play, and fell into a Conversation becoming them: and so passd the remainder of the Day. ${ }^{27}$

The Philosopher in Early Modern Europe: The Nature of a Contested Identity, eds Conal Condren, Stephen Gaukroger, and Ian Hunter (Cambridge: Cambridge University Press, 2006), pp. 254-75.

26 'Of Study', Journal, MS Locke f. 2, p. 123. The entry begins on 26 March 1677 and is interrupted by entries on other topics; it concludes in early May 1677. There is a transcription in The Educational Writings of John Locke: A Critical Edition with Introduction and Notes, ed. James L. Axtell (Cambridge: Cambridge University Press, 1969), pp. 405-22 (pp. 418-19). For convenience, I cite Axtell's transcription. See also Richard Yeo, 'John Locke's “Of Study” (1677): Interpreting an Unpublished Essay', Locke Studies, 3 (2003), 147-66.

27 Anthony Ashley Cooper, Third Lord Shaftesbury, to Jean Le Clerc, 8 February 1705, Epistolario, II, pp. 520-26 (p. 521). This event probably took place between 1667 and 1675 when Locke was a member of Shaftesbury's household in London; if so, it is too early for the Third Earl (1671-1713) to have witnessed. The story must have been passed down to him. 
Although he could be impatient with the raillery of aristocratic or polite society, Locke was far more agitated by the empty verbiage of the 'Schools'. He feared that 'unintelligible Terms' and bad intellectual habits instilled by university education would infect conversation more generally, rendering 'Philosophy ... unfit, or uncapable to be brought into well-bred Company, and polite Conversation' ${ }^{28}$ Locke believed that even select groups of friends had to guard against this outcome. He belonged to several small discussion groups: Robert Boyle's experimental circle in Oxford from about 1660, an informal group of friends referred to in the Essay, a salon hosted by Henri Justel in Paris in the mid 1670s, a group called the 'Lantern' in Rotterdam from late 1686 (with Furly), and the 'Dry Club' in his final decade at Oates (living with Francis and Damaris Masham). Probably for this last group, he drew up a set of rules to govern conversation among equals. All participants had to affirm 'Whether he loves and seeks truth for truth's sake; and will endeavour impartially to find and receive it himself, and to communicate it to others?' ${ }^{29}$ Although not directly implied in these rules, it is interesting that the first editor of this piece, Pierre Des Maizeaux, told readers that Locke had been worried about the propensity of 'men to cantonise themselves' ${ }^{30}$ As we shall see, Locke was indeed concerned about the ways in which social groupings - family, neighbourhood, clubs, and friends - affected the opinions and judgements of individuals.

\section{In the Company of Friends}

The role of friends as sounding boards was a common theme in humanist writings which, of course, drew on the classical literature. Seneca spoke of 'loyal' friends as those 'whose conversation soothes your distress, whose advice helps you make up your mind'. ${ }^{31}$ Bacon declared that thoughts and

28 'Epistle to the Reader', Essay, p. 10.

29 Locke, 'Rules of a Society, Which met once a week ... ', in Works, X, pp. 312-14 (p. 313). This first appeared in Des Maizeaux, A Collection of Pieces, pp. 358-62. For a comparison of this text with the 'Rules of the Dry Club', as found in MS Locke c. 25, fols 56-57, see Philip Milton, 'Pierre Des Maizeaux, A Collection of Several Pieces of Mr. John Locke, and the Formation of the Locke Canon', Eighteenth-Century Thought, 3 (2007), 255-91 (pp. 282-84).

30 'Dedication', Several Pieces of Mr. John Locke; also in Works, X, pp. 149-59 (p. 156).

31 Lucius Annaeus Seneca, 'On Tranquility of Mind', in Seneca: Dialogues and Letters, ed. and trans. C. D. Costa (London: Penguin, 1967), pp. 29-58 (pp. 41-42). 
feelings were clarified by the 'communicating of a man's self to his friend'. ${ }^{32}$ Montaigne agreed, but was candid about the limits: 'I love arguing and discussing, but with only a few men and for my own sake'. ${ }^{33}$ When Thomas Hobbes' reputation was being assailed, it was said that he did his cause no good by working too much alone. John Wallis (admittedly an enemy) alleged that 'He [Hobbes] Thinks too much, and Converses too little, either with Books, or Men'. ${ }^{34}$

Locke's endorsement of these humanist values was accompanied by an acute sensitivity to the dangers of solitude. By 1697 when he wrote The Conduct of the Understanding (once intended as an additional chapter of the Essay), he had put this perception in a psychological framework. Locke made two pertinent comments. First, he observed as a fact that when certain thoughts were fuelled by passions they could take possession of our minds. Under the tyranny of such a fixation - 'I call it a clog, for it hangs upon the mind so as to hinder its vigour and activity in the pursuit of other contemplations' individuals became locked up in themselves. When actively aroused by others,

they are like men brought to themselves from some remote region; whereas in truth they come no farther than their secret cabinet within, where they have been wholly taken up with the puppet, which is for that time appointed for their entertainment ... it carries them away from the company, where they should bear a part in the conversation. ${ }^{35}$

Secondly, he asserted that this condition was more likely in those who

converse but with one sort of men, they read but one sort of books, they will not come in the hearing but of one sort of notions: the truth is, they canton out

32 Francis Bacon, 'Of Friendship', in The Essays, ed. John Pitcher (London: Penguin, 1985), pp. 138-44 (p. 141).

33 Montaigne, 'On the Art of Conversation', p. 1046.

34 John Wallis, Hobbeus heauton-timorumenos (Oxford, 1662), p. 8, cited in 'General Introduction', in The Correspondence of Thomas Hobbes, ed. Noel Malcolm, 2 vols (Oxford: Clarendon Press, 1994), I, p. xxx. John Aubrey reported that Hobbes 'sayd, the want of Learned Conversation was a very great inconvenience, and that though he conceived he could order his Thinking as well perhaps as another, yet methinkes in the countrey in long time for want of good conversation, ones witt growes mouldy' (John Aubrey, Brief Lives ... and The Life of Thomas Hobbes of Malmesbury, ed. John BuchananBrown (London: Penguin Books, 2000), p. 431).

35 John Locke, Of the Conduct of the Understanding, in Works, III, p. 285 (in section 45).

Parergon 26.2 (2009) 
to themselves a little Goshen in the intellectual world ... but the rest of that vast expansum they give up to night and darkness, and so avoid coming near it. ${ }^{36}$

On this analysis, good conversation was not merely enjoyable and instructive; it was also essential for unbiased pursuit of truth. ${ }^{37}$

It is significant that this anxiety about solitude (and hence the indispensability of friends) appeared in Locke's letters during the political turmoil of the $1650 \mathrm{~s}^{38}$ Writing from his father's house in Pensford, Somerset, he reported that

I am in the midst of a company of mortall that know noething but the price of corne and sheepe ... besids these here are the quakers, the people of Goshen ... with light in their breast and smoake in their mouth. ${ }^{39}$

A few years earlier he had witnessed the arraigning of James Nayler and other dissident Quakers at Westminster Hall, London. As he told his father, he saw

\begin{abstract}
Nailer one man more and 3 or 4 women of the tribe all with white gloves and the womens heads in white baggs. their carriage was strange to me, one of the women made a continued humming noise. [they did not answer questions and, if they spoke, it was with] the cover and cunning of that language which others and I beleeve they them selves scarce understand. ${ }^{40}$
\end{abstract}

The Quakers were living in 'goshens' even though they were a group of friends (indeed, the Society of Friends). They felt sure in their breasts that they were guided by an inner light direct from God. They were 'enthusiasts', a condition awarded a separate chapter in the fourth edition of the Essay (1700).

36 Locke, Conduct of the Understanding, in Works, III, p. 209 (in section 3).

37 It is unlikely that Locke would have agreed with Cicero's view, as presented by Lipsius in On Constancy, p. 79: 'I am never less solitary than when I am alone; nor never less idle than when I am at leisure'. For a version of this position, see Boyle on 'self-conversation', in Boyle Papers, Royal Society of London, vol. 7, fol. 291; also in The Works of Robert Boyle, eds Michael Hunter and Edward B. Davis, 14 vols (London: Pickering and Chatto, 1999-2000), XIII, pp. 126-29.

38 He declared to a friend (possibly Thomas Westrowe): 'Oh for a Pilot that would steare the tossed ship of this state to the haven of happinesse!' (Locke to [Thomas Westrowe(?)], 8 November [1659(?)], Correspondence, no. 82).

39 Locke to W. J [Isaiah Ward(?)], [Aug 1659(?)], Correspondence, no. 68.

40 Locke to John Locke, senior, 15 November 1656, Correspondence, no. 30. 
Although they were a small, tight sect, Locke came to see the Quakers as exemplifying a more general feature of human nature: namely, that individuals bound together by strong emotions or sympathies influenced each other, often in deleterious ways. In a letter to 'Tom' of October 1659, Locke declared 'we are all Quakers here and there is not a man but thinks he alone hath this light within and all besids stumble in the darke' ${ }^{41}$

The role of friendship became involved in Locke's ongoing engagement with the intellectual conditions, and moral implications, of assent to belief and opinion. The problem, as he came to conceptualize it, was that each person's judgement on all manner of things was as much affected by social and psychological factors as by pertinent evidence and argument. 'Mankind', he noted in 1675 , 'is supported in the ways of virtue or vice by the society he is of, and the conversation he keeps, example and fashion being the great governors of this world'. ${ }^{42}$ While travelling in France between November 1675 and May 1679, he developed this theme, making several relevant entries in his journals. ${ }^{43}$ In a long entry (in effect, an essay) headed 'Of Study', begun on 26 March 1677, Locke argued that opinions are settled and fixed in our minds by conversation with those closest to us. Reading books, even studying a range of authors, would not unsettle these opinions if we thought and read with blinkers formed by patterns of praise and disapproval, often established in childhood and reinforced by the 'bands \& companys' into which the world is divided. ${ }^{44} \mathrm{He}$ returned to this point in other entries, insisting in December 1678 that conduct and belief were mainly ruled by perceptions of 'credit and reputation'. ${ }^{45}$ He noted that obsession with reputation, guided by the reigning

41 Locke to Tom [Thomas Westrowe(?)], 20 October 1659, Correspondence, no. 82.

42 'Philanthropy', MS Locke c. 27, fol. 30; also in Locke: Political Essays, ed. Mark Goldie (Cambridge: Cambridge University Press, 1997), pp. 225-26 (p. 225). This passage is endorsed by Locke as 'Philanthropy $\underline{75}$ ', but it is not in his hand. See J. R. Milton, 'Philanthropy, or the Christian Philosophers: A Possible Addition to the Lockean Canon', British Journal for the History of Philosophy, 1 (1993), 64-66.

43 Locke carried with him the manuscript ('De Intellectu') of the Essay, and sketched additions and refinements to it in his journals.

44 'Of Study', Journal, 4 April 1677, MS Locke f. 2, p. 117; also in Axtell, Educational Writings, p. 415.

45 'Credit, Disgrace', Journal, 12 December 1678, MS Locke f. 3, pp. 381-82 (p. 381); also in Locke: Political Essays, ed. Goldie, pp. 271-72 (p. 271). In a commonplace book entry dated 1693 (possibly 1694), under the heading 'Homo ante et post lapsum', Locke wrote that the Fall into 'coviteousness pride $\&$ ambition, which by fashen $\&$ example spread the 
fashion, could slant even apparently abstract intellectual commitments: it 'puts men upon school divinity in one country, and physic or mathematics in another', ${ }^{46}$ Never far below the surface was this apparently extreme case: 'The Quakers are a great instance, how little truth and reason operates upon mankind, and how great force society and conversation hath amongst those that maintain an inviolable friendship and concern, for all of their way, ${ }^{47}$

Thus friendship did not come without risks. Close friends could be trusted more than others but there was a risk that two or more people would constitute a 'club' and so be liable to delude each other. In his manuscript 'An Essay concerning Toleration' of 1667, Locke observed that 'Though force cannot master the opinions men have, nor plant new ones in their breasts, yet courtesy, friendship, \& soft usage may'. ${ }^{48}$ In the Essay, he summed up his thinking, announcing a 'Law of Fashion' that rendered human beings more responsive to the esteem or censure of others in 'their Company' than to the laws of God or the punishments of the state. As he put it, there is not

one of ten thousand, who is stiff and insensible enough, to bear up under the constant Dislike, and Condemnation of his own Club ... Solitude many Men have sought ... but no Body, that hath the least Thought, or Sense of a Man about him, can live in a Society, under the constant Dislike, and ill Opinion of his Familiars, and those he converses with.

(Essay, II.xxviii.12)

corruption which has so prevailed over mankind ... JL' (MS Locke c. 28, fol. 113; also in John Locke: Writings on Religion, ed. Victor Nuovo (Oxford: Clarendon Press, 2002), p. 231). See Peter Harrison, The Fall of Man and the Foundations of Science (Cambridge: Cambridge University Press, 2007), pp. 229-32 for the inference that Locke regarded the effects of the Fall as transmitted more by social conditioning than by inheritance.

46 'Credit, Disgrace', Journal, 12 December 1678, MS Locke f. 3, pp. 381-82 (p. 381); also in Locke: Political Essays, ed. Goldie, pp. 271-72. James Tully has argued that Locke's views on the social conditioning of belief crystallized during this period in France (James Tully, 'Governing Conduct: Locke on the Reform of Thought and Behaviour', in his An Approach to Political Philosophy: Locke in Contexts (Cambridge: Cambridge University Press, 1993), pp.179-241, esp. pp. 189-200).

47 'Philanthropy' (1675), MS Locke c. 27, fol. 30; also in Locke: Political Essays, ed. Goldie, pp. 225-26, (p. 225).

48 John Locke, An Essay Concerning Toleration and Other Writings on Law and Politics, 1667-1683, ed. J. R. and Philip Milton (Oxford: Clarendon Press, 2006), p. 297. This edition uses the version in Locke's hand now in the Huntington Library, San Marino, California. 
In treating the issue of 'wrong assent', Locke warned about 'giving up our Assent to the common received Opinions, either of our Friends, or Party; Neighbourhood, or Country' (Essay, IV.xx.17, original emphasis; also IV.xv.6). The challenge for each of us, as Locke posed it, was to recognize those factors determining our assent to beliefs. He hoped that 'a serious \& sober friend' might help us identify our prejudices, 'to examine these our received $\&$ beloved opinions'. ${ }^{49}$ But before coming to the qualities of such friends and the ways in which they might assist, it is important to consider how Locke's reflections on both conversation and friendship were expanded by his experiences as a traveller.

\section{Conversation Without Friendship: Exchanges With Strangers}

When it suited him, Locke could affect shyness. Late in his life, when seeking to avoid a government post, he explained that 'my temper, always shie of a crowd and strangers, has made my acquaintance few and my conversation too narrow ... I am too much a novice in the world for the imployment proposed' ${ }^{50}$ Even though understandable as a ploy to escape an unpalatable request, this seems disingenuous. Locke had taken a diplomatic post to Cleves in late 1665-66, spent years in the company of the Whig circle hosted by his mentor, Lord Shaftesbury, and been entrusted with the care of young aristocratic gentlemen in London and Europe. Nevertheless, Locke did betray what appears as a constitutional wariness about communication with others. In one of his commonplace books, there are two signed entries under 'Lingua' dated 1694: 'tell not your businesse, or designe to one that you are not sure will help it forwards. All that are not for you count against you. For soe they generally prove either through folly, envie, mallace or interest. JL'. And then at the bottom of the page: 'Doe not hear your self say to an other what you would not have an other hear from him. JL'. ${ }^{51}$ In the last year of his life, Locke told Anthony Collins that 'in my whole life I have been constantly against any thing that makes a shew, noe maxime being more agreeable to

49 'Of Study', Journal, MS Locke f. 2, p. 121; also in Axtell, Educational Writings, p. 417.

50 Locke to Sir John Somers, 28 January 1698, Correspondence, no. 2384.

51 'Adversaria 1661 ', p. 38. This is an unpublished manuscript; the original is now in private possession. Microfilm copies are held in the Bodleian Library, Oxford and the Houghton Library, Harvard (which I have used). For doubts that it could have been used as early as 1661, see J. R. Milton, 'The Dating of “Adversaria 1661”, Locke Newsletter, 29 (1998), $105-17$. 
my condition and temper than Qui bene latuit bene vixit' ('he who has lived well hidden has lived well'). ${ }^{52}$

Locke was himself a stranger while travelling in France. On his return to England (on 30 April 1679) he made entries about love of homeland in a commonplace book; both are initialled. ${ }^{53}$ Under 'Amor patria' he wrote:

The remembrance of pleasures and conveniences we have had there; the love of our friends whose conversation and assistance may be pleasant and usefull to us ... $\&$ seen more than others of the world \& the strange things in it; all these preserve in us long absence a constant affection to our country $\&$ a desire to return to it ... Whilst we are abroad we look on our selves as strangers there $\&$ are always thinkeing of departing we set not up our rest, but often see or thinke of the end of our being there $\&$ the minde is not easily satisfied with any thing it can reach to the end of. ${ }^{54}$

Locke may have come to realize that travellers enjoyed advantages: they could converse with other strangers with civility but not necessarily with a view to friendship. There is a revealing comment in his letter of 18 August 1677 to Sir John Banks, a wealthy English merchant. Having acceded to a request to act as a tutor and guardian to Banks' eighteen-year-old son, Caleb, who was undertaking the required European tour, Locke made this observation:

They who imagine that the improvements of forain conversation are to be sought by making acquaintance and friendships abroad, seeme to me wholy to mistake the matter, and it appears to me quite another thing. The great benefit to be found by travell is by constant changeing of company, and conversing every day with unknown strangers is to get a becomeing confidence and not to be abashed at new faces. ${ }^{55}$

52 Locke to Collins, 26 May 1704, Correspondence, no. 3544. See a reference to this motto in Pieter Guenellon to Locke, 8/18 May 1689, Correspondence, no. 1135. De Beer gives dual dates indicating the ten-day difference in the European and English calendars at the time. The Latin motto is possibly derived from Ovid, Trisitia III.iv.25. See de Beer, Correspondence, III, p. 617, n. 1; VIII, p. 301, n. 2.

53 'Patriae Armor' and 'Armor Patriae', MS Locke d. 1, pp. 53, 57. Both were entered in 1679.

54 'Armor Patriae', in Locke: Political Essays, ed. Goldie, p. 275.

55 Locke to Sir John Banks, 18/28 August 1677, Correspondence, no. 352. See Roger Woolhouse, Locke: A Biography (Cambridge: Cambridge University Press, 2007), pp. 130-38 on Locke's frustration in dealing with Banks and his son. 
In similar advice about a year later, he wrote: '[I think] travelling better for him then resting at Paris, where a young english gent, (especially if he be naturally bashfull) will be sure to flee the conversation of strangers and to heard [sic] always with his country men'. ${ }^{56}$ In other comments, which he noted privately, Locke thought that the traveller should withhold something of himself. Some time between May 1679 and early 1684, he made some short entries on this theme in a medical notebook. Under 'Malevoli', we find: 'To guard your self against the malicious envious, curious, which are the greatest part of men, Keepe not allways in the same tract. The best way to conceale your self is sometimes to be open. JL'. ${ }^{57}$ More positively, he noted that as a stranger one can take advantage of the fact that men are willing to convey what they know, to display their expertise. Thus he reflected under 'Conversatio':

In conversation gain esteem. goodwill knowledg \& where it is worth while interest. vertue \& abilitys gain esteem. goodwill good will for knowledg talke with every man of that wherein he hath skill by which commonly you learne \& obleige him at once, men being generally pleased more with teaching then learning. Obligations \& usefulnesse gives one interest, the first with gratefull men, the other with all. JL. ${ }^{58}$

What did strangers offer? It is worth distinguishing two kinds of conversation: first, those exchanges in which Locke sought information from strangers about various empirical matters, especially those relating to medicine and natural history; and second, those conversations he took as evidence of local customs, values, religious beliefs, and cultural practices. ${ }^{59} \mathrm{I}$ will briefly sketch these two interactions.

56 Locke to Dr. Thomas Coxe, 13/23 June 1678, Correspondence, no. 386. In one respect, Locke was doing no more than repeating the advice given in some of the leading courtesy manuals. Stefano Guazzo recognized the need to be comfortable in the company of the learned and ignorant, 'now with our owne Countriemen, then with straungers' (The Civil Conversation (first published in Italian 1574; English translation, 1581); cited in Peter Miller, Peiresc's Europe: Learning and Virtue in the Seventeenth Century (New Haven: Yale University Press, 2000), p. 56).

57 MS Locke f. 24, fol. 93 ; also in Locke, An Essay Concerning Toleration, eds Milton and Milton, p. 394.

58 MS Locke f. 24, fol. 31' $1^{\text {r }}$ also in Locke, An Essay Concerning Toleration, eds Milton and Milton, p. 394.

59 This division is reflected in Locke's use of the categories 'physica' and 'ethica' to describe some of his notebooks; for example, the two parts of MS Locke c. 42; and also in MS Locke d. 10 and d. 11 which are titled, respectively, 'Lemmata Ethica' and 'Lemmata 
While in France, Locke kept four journals, comprising some 1500 pages of notes. ${ }^{60}$ A considerable proportion of the information he collected was supplied by strangers. To a significant extent, he needed introductions and tips from English residents, such as William Charleton (actually Courten) in Lyon and the Countess of Northumberland, the wife of the English Ambassador, Ralph Montagu, in Paris. In Montpellier he tapped into the medical circles, meeting Charles Barbeyrac, Pierre Magnol, and Pierre Jolly, as well as the young Thomas Pembroke. Locke seemed aware of this dependence, or at least he did by the end of his stay. About a week before leaving Paris for London he joked that his friends were only now telling him about things he should see. ${ }^{61}$ But it is clear that he also tried to talk directly with people he met in Montpellier and Paris, while travelling in Provence and Languedoc, and on his return trip to Paris in early 1677. Locke spoke with peasants in the fields, gardeners, fruit cultivators, wine makers, artisans, craftsmen, clerics, apothecaries, and physicians. ${ }^{62}$ These people told him what to look for, what to see, who to ask. He usually recorded the names of his informants, especially when the content was facts about the plants, animals, or medicinal remedies and treatments. ${ }^{63}$ In many other instances, he noted only trade or

Physica'. However, the seventeenth-century category of natural history could include local customs, as Locke often does.

60 Locke had previously accompanied the Earl and Countess of Northumberland on a threeweek visit to Paris in 1668. For the main French sojourn, November 1675-May 1679, see Cranston, John Locke, pp. 160-83; Woolhouse, Locke, pp. 119-52. Locke's journals are in MS Locke f. 1, f. 2, f. 3, and British Library (subsequently BL) Add MS 15,642. Extracts are printed in Locke's Travels in France 1675-1679 as Related in His Journals, Correspondence and Other Papers, ed. John Lough (Cambridge: Cambridge University Press, 1953). If the entry is in Lough's transcriptions, I cite his text; in other cases I give Locke's original pagination.

61 'Rarities, Stones', Journal, 2 May 1679, in Locke's Travels, ed. Lough, p. 273; Locke to Nicolas Toinard, 27 and 28 April/7 and 8 May 1679, Correspondence, no. 467.

62 Journal, 8 and 10 March 1676; 18 July 1676; 7 July 1677, in Locke's Travels, ed. Lough, pp. 56, 105, 155.

63 See Journal, 9 May 1676; 9 August 1676; and 20 June 1678, in Locke's Travels, ed. Lough, pp. 92, 108, 200. Lough omits most medical and philosophical entries. For selections of the former, see Kenneth Dewhurst, John Locke (1632-1704) Physician and Philosopher: A Medical Biography (London: Wellcome Historical Medical Library, 1963), pp. 62-151; and for the latter, see An Early Draft of Locke's Essay On the Human Understanding Together with Excerpts from his Journals, eds Richard I. Aaron and Jocelyn Gibb (Oxford: Clarendon Press, 1936), pp. 75-125. 
profession; and when summarizing his conversations with groups of people he used referents such as 'they', 'some', or 'a few', thereby capturing the range of opinions on a particular topic within a community. For example, in summarizing the opinions in Montpellier about pressing olives, he noted that 'All confesse that oyle is better which is made of Olives fresh gatherd ... Others say the reason why they are not pressed sooner is because every body's grist cannot be ground at once, \& they must stay till they can get a turne'. In recording local estimates about the number of small county houses (bastides) near Marseilles, he wrote that 'some tell you, 22,000. They that speake lowest say 16 or $17,000{ }^{\prime}{ }^{64}$

In these exchanges, Locke mainly recorded what he was told. He recognized that there were good and bad reporters; occasionally he wrote 'dubio' (I doubt it) next to an entry. In the great majority of cases, he was seeking local knowledge about natural processes and causal properties that were novel to him. He sometimes contrasted published reports with his (or others') firsthand observations. ${ }^{65}$ Depending on the subject matter, he seems to have been more concerned with the skill and expertise, rather than the social status, of the informants. ${ }^{66}$ Although in the Essay (IV.xvi.4) he gave the 'Integrity' of witnesses as one of the six criteria for the evaluation of testimony, this could not feasibly be applied to all people, and so Locke noted empirical facts as reported. ${ }^{67}$ Thus he entered a detailed note on silkworms as explained to him by the wife of his landlord (Monsieur Fesquet) in Montpellier. ${ }^{68}$ Making notes about how plums, peaches and pears were dried, he wrote 'this was taught me

64 Journal, 10 February 1676, in Locke's Travels, ed. Lough, p. 37; and 11 April 1676, p. 75.

65 'Revel Reservoir', Journal, 4 March 1677, in Locke's Travels, ed. Lough, p. 128.

66 For the importance of this attitude to the exchange of information, see David S. Lux and Harold J. Cook, 'Closed Circles or Open Networks?: Communicating Science at a Distance During the Scientific Revolution', History of Science, 36 (1998), 179-211. For Locke's contribution to such an informal network, see Stephen Harris and Peter Anstey, 'John Locke's Seed Lists: A Case Study in Botanical Exchange', Studies in History and Philosophy of Biological and Biomedical Sciences, 40 (2009), 256-64.

67 Steven Shapin places Locke's rules in the context of similar maxims offered by contemporaries such as Boyle (A Social History of Truth: Civility and Science in Seventeenth-Century England (Chicago: The University of Chicago Press, 1995), pp. 212-32).

68 'Silk wormes', Journal, entries from 2-21 June 1676, in Locke's Travels, ed. Lough, pp. 95-102. 
by Madame de Superville'. ${ }^{69}$ While travelling to Paris he made an entry under the marginal heading of 'Vines': 'To make vines beare in barren ground, put a sheep's horne to the root \& it will doe wonders.' 70 Later, when he wrote up the material he gathered on wine making and other agricultural practices, Locke repeated this note, adding 'I have no great faith in it, but mention it because it may so easily be tried'.71 This procedure made sense because he believed that strong theoretical judgements must be postponed until information on particular topics was more fully collated. But first it had to be gathered, if not by personal observation, then by approaching the right sources. Masham said that Locke believed 'he could learn something which was usefull, of every body'; and that he accomplished this by 'suteing his Discourse to the Understanding, and proper skill of every one he convers'd with.' 72 Indeed, Locke confirmed this, saying that talk with jewellers, blacksmiths, gardeners or others skilled in a particular science or art yielded more accurate information than conversation with polite gentlemen (Essay, II.xxiii.3).

Another of Locke's abiding concerns - the diversity of customs and beliefs - is also evident in the journals. Here we see a different kind of conversation. Locke made many notes about the religious rituals and moral beliefs of people in various parts of the country. There are some scathing comments, some in shorthand for secrecy, about Catholic rituals he witnessed.73 He showed the appetite of an anti-Papist for scurrilous stories about priests, bishops, nuns, and the theatre of the liturgy. On 11 February 1679 he recorded the account of a French visitor and his wife attending 'a Masse [in Rome] where the pope was present'. After the elevation of the host, a 'very considerable cardinall' asked the visitor: 'Che dice vostra signioria di tutta questa fanfanteria

69 'Pears drying', Journal, 15 August 1678, in Locke's Travels, ed. Lough, p. 220.

70 'Vines', Journal, 19 May 1677, in Locke's Travels, ed. Lough, p. 144.

71 John Locke, Observations upon the Growth and Culture of Vines and Olives: The Production of Silk: The Preservation of Fruits (London: W. Sandby, 1766), p. 7.

72 Masham to Le Clerc, Epistolario, II, p. 511. Compare Boyle's more aristocratic stance in his remark that he intended 'to catechise my gardner and our ploughmen, concerning the fundamentals of their profession' (Robert Boyle to Benjamin Worsley, after 21 November 1646, in Robert Boyle, Correspondence of Robert Boyle, eds Michael Hunter, Antonio Clericuzio, and Lawrence M. Principe, 6 vols (London: Pickering and Chatto, 2001), I, p. 43).

73 Although shorthand provided partial secrecy, Locke sometimes used it for weather observations, and occasionally recorded quite delicate matters in longhand. See Locke's Travels, ed. Lough, pp. lxiv-lxv. 
[furfanteria?]?' ['What does your wife say about all this trickery?'] ${ }^{74} \mathrm{He}$ may have been aware that he did not hear full disclosures: for example, when noting (partly in shorthand) the severe initiations and punishments of the Capuchins, he mentioned the embarrassment caused 'once when a stranger was there' ${ }^{75}$ Yet even when Locke showed his annoyance with local beliefs about relics and miracles, the descriptive detail of his accounts made them potential data for a natural history of religion, and more generally, of opinion. ${ }^{76}$ Alongside these observations of Catholic practices, Locke collected comparative information about the culture of the Muslim world, the Indies, and the Americas, both from books and travellers. ${ }^{77}$ When he got home he transferred several entries to commonplace books under the headings of 'Ethica' or 'Cultus', thus recording the diverse morals, beliefs, customs, and rituals of various countries and peoples. ${ }^{78}$ On 17 June 1679, he observed in his journal that most men 'take the common belief or opinion of those of their country, neighbourhood or party to be proof enough, and so believe as well as live by fashion and example, and thus men are zealous Turks as well as Christians. JL'. ${ }^{79}$ We can take this as a conclusion justified and amplified by his experiences as a traveller.

In summary, Locke's conversation with strangers was a major source of new empirical information on a range of topics, especially those pertaining to causal properties in nature. Secondly, the conversations of strangers provided more extensive and comparative illustration of what he already thought about the influence of customs on opinions and beliefs. As a traveller, Locke may

74 'Popery', Journal, 11 February 1679, in Locke's Travels, ed. Lough, p. 257. This entry is not in shorthand, but one on the 'Jesuits' (13 February) is.

75 'Capuchins', Journal, 19 March 1679, in Locke's Travels, ed. Lough, p. 262. He may have got this account from Père Chérubin, a Capuchin who worked on optics (Locke's Travels, ed. Lough, p. lix).

76 'Reliques, Miracles', Journal, 23 August 1678; and 'Reliques', 6 October 1678, in Locke's Travels, ed. Lough, pp. 223-24, 242.

77 See for example, 'Turks', Journal, 19 September 1677, MS Locke f. 2, pp. 270-71 (not printed in Lough).

78 See MS Locke c. 42, Part II, pp. 6, 14, 16, 22; and MS Locke d. 1, pp. 5, 9, 53, 81. See also Daniel Carey, Locke, Shaftesbury, and Hutcheson: Contesting Diversity in the Enlightenment and Beyond (Cambridge: Cambridge University Press, 2006), esp. Chapters $1-3$.

79 'Opinion', Journal, 17 June 1679, BL Add MS 15,642, p. 101; also in Locke: Political Essays, ed. Goldie, p. 274. I use Goldie's transcription.

Parergon 26.2 (2009) 
have been temporarily free of clubs, neighbourhood, country, and established friendships. However, the natural history of opinion he collected led him back to the role of friends. In fact, it was through conversation with some strangers that Locke made new friends, some of whom remained correspondents for the rest of his life. ${ }^{80}$ Could such strong relationships protect the individual against the twin dangers of solitary thinking and the inertia of custom? Locke seems to have thought so, but given his conviction about the force of fashion and flattery, he decided that the pursuit of truth was something that had to be cultivated as a desire, as a counter-balancing passion. Significantly, he made this point in the entry 'Of Study' as part of his argument that these social and psychological factors influenced judgements. It was, he said, our duty to seek knowledge with 'a mind covetous of truth' ${ }^{81}$ One way to do this was to expose and examine our deepest prepossessions, those 'darlings of our mindes', as he called them, through 'conversation $\&$ discourse with an ingenious friend' ${ }^{82}$ In the manuscript of 1675 (previously cited), he specified another requirement: such friends should ideally be 'lovers of truth'. ${ }^{83}$ What Locke meant by this became clearer in letters to a new friend in the last decade of his life.

\section{A Special Friendship with William Molyneux}

On his own disclosure, one of Locke's closest friendships was the relatively short, but important, relationship with the Irish politician and philosopher, William Molyneux (1656-98).$^{84}$ Locke first wrote to Molyneux on 16 July 1692,

80 In France these included Nicolas Toinard, Justel, Magnol, Jean Le Clerc, and Pieter Guenellon. He also made new friends while exiled in Holland between September 1683 and February 1689, especially Furly and Limborch, and he renewed his friendship with Guenellon, who had returned to Amsterdam.

81 Journal, 5 April 1677, MS Locke f. 2, p. 117; also in Axtell, Educational Writings, p. 415. In an earlier entry Locke wrote that 'Desire ... is nothing but a pain the mind suffers in the absence of some good' ('Desire', Journal, 16 July 1676, MS Locke f. 1, p. 340; in Locke, Essays on the Law of Nature, p. 270). This is therefore an early statement of his view that the search for truth has to be made a desire.

82 'Of Study', Journal, MS Locke f. 2, pp. 121, 109; also in Axtell, Educational Writings, pp. 417, 412-13.

83 'Philanthropy', 1675, MS Locke c. 27, fol. 30; also in Locke: Political Essays, ed. Goldie, p. 226.

84 For Molyneux's intellectual setting, see K. Theodore Hoppen, The Common Scientist in the Seventeenth Century: A Study of the Dublin Philosophical Society 1683-1708 (London: Routledge, 1970). 
thanking him for the gift of his book, Dioptrica Nova (1692), and interpreting it as indicating 'great advances of friendship towards me' ${ }^{85}$ Molyneux replied, declaring himself a fan of the Essay and its author. Thus began a six-year correspondence between the now famous English philosopher and an Irish MP twenty-four years his junior. ${ }^{86}$ In a letter of 26 April 1695, Locke wrote that 'You look with the eyes, and speak the language of friendship' ${ }^{87}$ In fact they had not met, and did not do so until Molyneux visited London between July and early September 1698, staying with Locke at Oates. Molyneux arrived back in Dublin on 15 September and died of kidney failure on 11 October 1698. Thus in spite of Locke's stress on the value of face-to-face conversation, their friendship was formed at a distance. As a partial remedy they commissioned portraits of themselves from Sir Godfrey Kneller; but these were not completed until after Molyneux's death. Locke's amanuensis, Sylvester Brounower, reported in November 1698 that 'Mr Molineux's picture is not yet finish'd, nor is yours' ${ }^{88}$

This unusual relationship is one of the few that has produced written evidence that Locke consulted friends about the content of the Essay. Even so, this occurred after the publication of the first edition. Molyneux stimulated Locke to make important revisions - especially to the chapter 'Of Power' and also additions, such as the new chapter on 'Identity and Diversity' (Essay, II.xxvii). ${ }^{89}$ Since Molyneux agreed with Locke on most issues there is the

85 Locke to William Molyneux, 16 July 1692, Correspondence, no. 1515; Molyneux to Locke, 27 August 1692, Correspondence, no. 1530. Strictly speaking, Molyneux wrote the first letter on 7 July 1688 (no. 1064), addressing the 'Author of the Essai Philosophique concernant L'Etendement', which was the Abrégé of the Essay published in the Bibliothèque Universelle, 8 (1688), 49-142. His question was: assume a blind man who can distinguish between a globe and a cube by touch; if his sight were restored, would he be able to discriminate between them by sight alone? He put his question directly to Locke again on 2 March 1693 (no. 1609). This came to be known as 'the Molyneux Problem'.

86 In the Correspondence, there are sixty-seven letters between Locke and Molyneux. These were first published in Some Familiar Letters between Mr. Locke and Several of His Friends (London: Churchill, 1708) and reprinted in Locke, Works, IX, pp. 285-472. On this, see Correspondence, I, pp. xliii-xviv.

87 Locke to Molyneux, 26 April 1695, Correspondence, no. 1887.

88 Sylvester Brounower to Locke, 1 November 1698, Correspondence, no. 2505.

89 See, for example, Molyneux to Locke, 22 December 1692, Correspondence, no. 1579, for a series of suggestions; and Locke to Molyneux, 23 August 1693, Correspondence, no. 1655 for his admission that the chapter 'Of Identity and Diversity' was 'writ only at your 
possibility that Locke was open to the flattery he warned against; although it must be said that their friendship withstood a major disagreement over Irish policy. ${ }^{90}$ It is also worth emphasizing that their relationship developed during the 1690s while Locke was living in Damaris Masham's house and already had regular correspondence with close friends such as Furly and Limborch. His declaration of a unique friendship with Molyneux therefore needs to be treated with caution; but it remains an intriguing one, almost as if Molyneux is the perfect stranger, the knowledgeable person not influenced by the complicating emotions involved in most friendships.

The dominant theme of this correspondence was that friends helped each other find truth. On several occasions, Locke stressed that clarity was not to be found in solitary thought: 'I should think he valued himself more than truth, and presum'd too much on his own abilities, who would not be willing to have all the exceptions could be made by any ingenious friend, before he ventur'd any thing into the publick'. ${ }^{91}$ Two years later he reiterated this theme: 'Meditating by ones self is like digging in the mine; it often, perhaps, brings up maiden earth, ... but whether it contain any mettle in it, is never so well tryd as in conversation with a knowing judicious friend' ${ }^{92}$ Locke even seemed to put aside his usual caveats about the slipperiness of language preventing clear exchange of ideas. In fact, he detected in Molyneux an ability, not found in 'ordinary readers', to discern 'the design and foundation of what I say, rather than stick barely in the words', and told him that 'You understand my thoughts as well as I do my self' ${ }^{93}$

Locke quickly decided that Molyneux was a 'lover or seeker of truth' - an attribute he awarded in a letter of 26 December 1692, having already

instance'. See J. G. Simms, William Molyneux of Dublin, 1656-1698, Chapter 6, for the philosophical topics covered in their correspondence (ed. P. H. Kelly (Blackrock, County Dublin: Irish Academic Press, 1982)). Locke also exchanged letters with Limborch about his treatment of the question of freedom of the will.

90 See Patrick Kelly, 'Locke and Molyneux: The Anatomy of a Friendship', Hermathena, 126 (1979), 38-54.

91 Locke to Molyneux, 20 January 1693, Correspondence, no. 1592.

92 Locke to Molyneux, 26 April 1695, Correspondence, no. 1887.

93 Locke to Molyneux, 20 January 1693, Correspondence, no. 1592 and 8 March 1695, Correspondence, no. 1857. See Hannah Dawson, Locke, Language and Early-Modern Philosophy (Cambridge: Cambridge University Press, 2007), p. 214. These remarks bear on Locke's aim to uncover the intention behind St Paul's epistles. See Nuovo, John Locke: Writings on Religion, p. xxxviii. 
announced himself as one of these. ${ }^{94}$ Locke gave this commendation sparingly, declaring that 'so few are to be found'. ${ }^{95}$ In the second edition of the Essay (1694) he stated that as 'a Lover of Truth, and not a Worshipper of my own Doctrines, I owne some change of my Opinion'. He explained that he had altered his earlier account of the ideas of 'Will, Volition, Liberty, and Necessity', as they were treated in the chapter 'Of Power', after criticism from friends, especially one 'very judicious friend of mine', namely, Molyneux. ${ }^{96}$ In effect, Locke was saying that he had done what a lover of truth should do: he had changed his opinion after critical dialogue with a trusted friend. Molyneux praised this action, saying that the 'Candid recession from your Former Hypothesis ... where Truth required it, raises in me a Greater Opinion (if possible) of your Worth than ever'.97

This vexed issue of liberty in action and belief was what Locke called a matter of 'concernment', along with those bearing on our long-term health, happiness, and future salvation. Such issues demanded that 'a due examination be made, proportionable to the weightiness of the matter, and the concernment it is to us not to mistake' (Essay, 2nd edn, II.xxi.66). There was a duty to 'raise our desires, in a due proportion to the value of that good, whereby in its turn, and place, it may come to work upon the will, and be pursued'. On his revised account, Locke was adamant that this was feasible because the mind had 'a power to suspend the execution and satisfaction of any of its desires' and to give these matters of concernment 'due and mature Examination' (Essay, 2nd edn, II.xxi.46, 47, 52). ${ }^{98}$ Friends might help each other to conduct such an examination, but Locke set the bar very high: not all friends were 'lovers of truth'; 'A rational free-minded man, tyed to nothing but truth, is so rare a thing, that I almost worship such a friend'. ${ }^{99}$ About a month later he acknowledged that

94 Locke to Molyneux, 26 December 1692, Correspondence, no. 1583; and 20 September 1692, Correspondence, no. 1538.

95 Locke to Molyneux, 26 December 1692, Correspondence, no. 1583.

96 Locke, An Essay Concerning Humane Understanding, 2nd edn (London: Thomas Dring and Samuel Manship, 1694), II.xxi.72 (p. 151).

97 Molyneux to Locke, 28 July 1694, Correspondence, no. 1763.

98 For Locke's stress on each individual's responsibility in these matters, see Dunn, 'Bright Enough for all our Purposes'.

99 Locke to Molyneux, 6 April 1698, Correspondence, no. 2414; 8 March 1695, no. 1857; and 28 March 1693, no. 1620. 
I cannot complain that I have not my share of friends of all ranks, and such, whose interest, assistance, affection, and opinions too, in fit cases, I can rely on. But methinks, for all this, there is one place vacant, that I know no body that would so well fill as your self. ${ }^{100}$

In these comments, Locke appears to refer to something like the Stoic notion of a close friendship between two equally wise and virtuous individuals. Margaret Graver explains that this was a normative ideal because 'given the scarcity of even individual wise persons it seems unlikely that two or more of them could ever come to know one another in fact' ${ }^{101}$ It appears, however, that Locke was more concerned with the search for truth than the perfect friendship. Certainly, he thought that lovers of truth helped each other to make informed judgements, always providing that individuals were responsible for their own assent to beliefs on matters of the highest ethical and religious importance. Thus in a letter to Limborch about his attempt to analyse 'the condition of human liberty', he declared: 'But the opinions of friends often deceive or are deceived, and these things having to be left to the censure of strangers, in this one thing alone I find satisfaction, that I have pursued the truth alone'. ${ }^{102}$ There was another consideration that put knowledge and truth above close friendship: Locke was aware that new empirical data, and the generalizations and practical applications founded on it, depended on collaboration. He was committed to an interpretation of the Baconian project that stressed co-operative observation, experiment, and controlled theorizing over many generations. ${ }^{103}$ Endorsing this programme in a letter to Molyneux about Boyle's General History of the Air (1692), Locke explained that this work was left unfinished, but that

it is cast into a method that any one who pleases may add to it, under any of the several titles [headings], as his reading or observation shall furnish him with matter of fact. If such men as you are, curious and knowing, would join to what Mr. Boyle had collected ... we might hope in some time to have a considerable history of the air ...; but it is a subject too large for the attempts of any one

100 Locke to Molyneux, 26 April 1695, Correspondence, no. 1887; also 5 April 1696, Correspondence, no. 2059.

101 Graver, Stoicism and Emotion, p. 175.

102 Locke to Limborch, 13 January 1694, Correspondence, no. 1692.

103 See Peter Anstey, 'Locke on Method in Natural Philosophy', in The Philosophy of John Locke: New Perspectives, ed. Peter Anstey (London: Routledge, 2003), pp. 26-42. 
man, and will require the assistance of many hands to make it a history very short of compleat. ${ }^{104}$

On this perspective, it did not matter if there was 'little friendship in the world'; ${ }^{105}$ what counted were open, informal exchanges, either in conversation or more often by letter, among interested individuals. The scale and diversity of the potential information demanded large numbers of people in different places, thereby requiring individuals to reach beyond the circle of close and intimate friends.

\section{Conclusion}

Damaris Cudworth (Masham) told Locke that there were "many Different Degreese of Friendship', partly because 'under the Name of Friends, which in Confomitie, I as well give to People that I do not much Care for as to those that I doe'. ${ }^{106}$ No doubt Locke agreed with this, for he valued conversations across the full spectrum from close intellectual engagement with a few friends to more varied exchanges with a wide range of people. His emphasis on friends as lovers of truths - as expressed in the correspondence with Molyneux - might appear to imply an exclusiveness that conflicts with this. However, the dissonance is partly resolved by his distinction between matters of concernment and matters of fact. Locke was not always seeking the kind of critical dialogue expected from close friends. His more general reflections on conversation and his own travel journals show a willingness to converse extensively, to pick up new information wherever possible, even if its reliability might be questionable. ${ }^{107}$ Locke recognized that proper evaluation involved a collective pooling of experience and information, much of which was of necessity derived from strangers.

104 Locke to Molyneux, 26 December 1692, Correspondence, no. 1583. Locke supervised this work through the press just after Boyle's death; it included his own register of the weather between 24 June 1666 and 30 June 1683. See Robert Boyle, The General History of the Air, Designed and Begun by the Hon. Robert Boyle (London: A. and J. Churchill, 1692), in Works of Boyle, XII, pp. 3-159 (pp. 70-89).

105 Bacon, 'Of Followers and Friends', in The Essays, ed. Pitcher, pp. 205-06 (p. 206).

106 Damaris Cudworth [later Lady Masham] to Locke, 14 August 1682, Correspondence, no. 726.

107 Daniel Carey, 'Travel, Geography, and the Problem of Belief: Locke as a Reader of Travel Literature', in History and Nation, ed. Julia Rudolph (Lewisburg.: Bucknell University Press, 2006), pp. 97-136. 
Locke accepted the value of 'weak ties' outside the stronger bonds of friendship. ${ }^{108}$ These loose, often transient, relationships were crucial for communication within the diffuse Republic of Letters and the nascent scientific community of early modern Europe. In hindsight, we might see them as a step towards a modern scientific ethos in which anonymity, neutrality, and objectivity became the vaunted arbiters of knowledge claims. In principle, these values supported norms (agreed by convention) that transcended personal friendships and even, perhaps, the need for conversation. ${ }^{109}$ For Locke, this moment had not yet arrived. With his contemporaries, he still relied on conversation and travel as conduits for new empirical information; in his own pursuit of truth, and for the evaluation of ideas and opinions, he sought intimate conversation with friends.

Centre for Public Culture and Ideas Faculty of Humanities and Social Sciences Griffith University ${ }^{110}$

108 This is a term from modern social network theory; see Lux and Cook, 'Closed Circles', pp. 181-82, 202.

109 Robert K. Merton, 'The Normative Structure of Science', in The Sociology of Science: Theoretical and Practical Investigations, ed. N. W. Storer (Chicago: The University of Chicago Press, 1973), pp. 267-78 (p. 276). Compare the perspectives in Lorraine Daston, 'The Ideal and Reality of the Republic of Letters in the Enlightenment', Science in Context, 4 (1991), 367-86; and Lorraine Daston and Peter Galison, Objectivity (New York: Zone Books, 2007), esp. Chapter 4.

110 For very helpful comments on this article, I thank Jacqueline Broad, Haig Patapan, Vanessa Smith, Mary Louise Yeo, and two anonymous referees for this journal. I am grateful to the Australian Research Council (ARC) for the Professorial Fellowship that supported this work; and to Griffith University for research leave. Membership of the ARC Network for Early European Research gave me access to crucial databases. 
Copyright of Full Text rests with the original copyright owner and, except as permitted under the Copyright Act 1968, copying this copyright material is prohibited without the permission of the owner or its exclusive licensee or agent or by way of a license from Copyright Agency Limited. For information about such licences contact Copyright Agency Limited on (02) 93947600 (ph) or (02) 93947601 (fax) 